\title{
La capătul îndepărtat al diacroniei: spirala evolutivă a apariției limbajului. O teorie
}

\author{
Adina Chirilăa \\ Facultatea de Litere, Istorie și Teologie, Universitatea de Vest, Bd. Vasile Pârvan 4, 300223 Timişoara, România
}

\author{
Despre articol \\ Istoric: \\ Primit 24 octombrie 2019 \\ Publicat 7 noiembrie 2019 \\ Cuvinte-cheie: \\ neurolingvistică \\ neuroni oglindă \\ ipoteza sistemului oglindă \\ formarea limbilor
}

\begin{abstract}
Rezumat
Între eforturile analitice care urmăresc asiduu chestiunea apariției limbajului articulat și, eventual, a formării mecanismului cerebral care l-a făcut posibil, ipoteza sistemului oglindă elaborată de Michael A. Arbib este una foarte bine articulată, grație abordării interdisciplinare. Articolul de față scoate în evidență cîteva elemente cruciale din procesul elaborării ei și îi expune esența: 1. nu există o gramatică universală înnăscută; 2 . starea propice limbii este multimodală - a evoluat ca sistem multimodal manual/facial/vocal, în trepte: a) la bază, protosemnul (protolimbaj gestual, cu un repertoriu deschis de semne); b) apoi, protovorbirea (protolimbaj vocalizat), care a pus la dispoziție „masa neurală critică” grație căreia c) limbajul s-a dezvoltat din protolimbaj, ca rezultat al inovațiilor culturale; 3 . mecanismele cerebrale care susțin limbajul au evoluat deasupra unui mecanism primitiv pre-hominid fără legătură, inițial, cu comunicarea; acesta, i.e. sistemul oglindă responsabil de apucare, a oferit fundamentul evolutiv pentru paritatea lingvistică.
\end{abstract}

Prolog. Un număr considerabil de articole și cărți-fie ele adresate unui public riguros specializat ori unuia doar superficial interesat de probleme științifice-ce au ca obiect aşa-numiții neuroni oglindă (sau numai se ancorează în știința despre aceștia pentru explicarea a diverse fenomene comportamentale) își rezervă cel puțin un paragraf pentru a rezuma istoria descoperirii lor în cortexul frontal al maimuțelor macac (regiunea premotoare ventrală, numită F5, apoi în lobulul parietal inferior-incluzînd ariile intraparietale laterală și ventrală, precum și în cortexul premotor dorsal și cortexul motor primar), acum douăzeci și șapte de ani (Di Pellegrino et al., 1992; v. și Rizzolatti et al., 1996; Gallese et al., 1996; Fogassi et al., 2005 etc.). Prin asemene lucrări s-a înțeles repede că este vorba de neuroni vizuo-motori ce reacționează la observarea actelor motorii executate de un alt individ, proprietatea lor specială fiind aceea că creează o anumită identitate între observarea actelor motorii manuale sau orale și executarea unor acte motorii identice sau asemănătoare (Rizzolatti \& Fogassi, 2014); mai simplu spus, sistemul neuronal în discuție utilizează un singur cod neuronal pentru două capacităţi raţionale: observarea și executarea acțiunilor. Urmarea este că mecanismul asigură individului observator înțelegerea automată-i.e. înțelegere fără procesare inferențială — a acțiunii motoare a individului observat (Rizzolatti \& Fogassi, 2014), stabilinduse o conexiune între observator și individul observat.

Cînd și cît a fost posibil, cercetările efectuate asupra subiecților umani (Molenberghs et al., 2013; Mukamel et al., 2010; Kilner et al., 2009; Chong et al., 2008; Press et al., 2012) au confirmat existența unei largi corespondențe între ariile corticale active la observarea-executarea acțiunilor și ariile în care sau evidențiat neuronii oglindă la macaci, ceea ce a dat posibilitatea formulării ipotezei că un sistem al neuronilor oglindă este prezent și funcțional și în creierul uman (Kilner et al., 2013, p. 1060-1061).

Efectul, pe de o parte, al expunerii repetate a mecanismului neuronilor oglindă și, pe de altă parte, al expunerii lui într-o manieră mai degrabă simplificată, ce lăsa în umbră multiple aspecte neelucidate ${ }^{1}$, a fost

\footnotetext{
*Adresă de corespondență: chiriladina@yahoo.com.

${ }^{1} \mathrm{O}$ expunere succintă a certitudinilor obținute în urma cercetărilor, a limitelor (unele, încă!) nedepăşite, precum și a riscurilor aplicării ipotezei neuronilor oglindă în lipsa unei înțelegeri depline a fenomenelor se găsește la Kilner et al. (2013).
} 
că în mintea omului cultivat, dar totuşi de masă, s-a instalat puternică și strălucitoare ideea că această clasă de neuroni vizuo-motori este piatra unghiulară din edificii mai mult sau mai puțin vag exprimate, de la cogniție socială și „marele salt” (Heyes, 2010) în evoluția omului, pînă la fenomene, abilități ori tulburări precum limbajul articulat, schizofrenie, hipnoză, percepția (uneori dureroasă) a membrelor amputate, psihopatie, fumat, îndrăgostire, empatie, autism, halucinații paranoide sau... atitudini politice.

Se părea că totul și orice putea fi explicat prin acțiunea neuronilor oglindă, deși, în adevăr, numai o parte a cercetărilor reușise să-şi demonstreze irefutabil (ori măcar peremptoriu) ipotezele, urmînd o metodologie cen-ar fi lăsat loc concluziilor pur speculative, dar atît de entuziaste și seducătoare pentru public. Aparenta atotcuprindere teoretică a făcut însă și ca, la un moment dat, explicația să se prăbușească sub greutatea propriei sale popularități, suspiciunea legitimă în privința funcției pe care ar îndeplini-o acești neuroni la nivelul unui fenomen oarecare extinzîndu-se fără discernămînt asupra multor altora. Ca în multe alte cazuri, observatorului instruit îi revine sarcina de a alege grîul de neghină-demers la fel de dificil atunci cînd totul vrea să i se vîndă drept grîu, ca și atunci cînd totul vrea să i se vîndă drept neghină.

TEмA. Între fenomenele sau abilităţile ce țin de ființa umană, limbajul a fost printre primele a căror explicație s-a încercat a fi găsită în conexiune cu neuronii oglindă.

Știința nu duce lipsă de scenarii ale apariției limbajului articulat ${ }^{2}$, complementare ori declarat antagonice ${ }^{3}$, de fiecare dată cercetătorii (nerăbdători să intre în joc mai ales din arii din ce în ce mai ne-lingvistice-e.g. biologie, neurologie, științe computaţionale, inginerie-și din ce în ce mai eclectice) străduindu-se să coboare cu încă o generație evolutivă înspre „momentul” manifestării eficiente a acestuia în grupul de indivizi. Impresia este însă a unei supărătoare neputințe de a trece dincolo de schițarea conjecturală a unor posibile/probabile circumstanțe sociale care să fi stimulat fenomenul—o necesitate a mediului: economică și/sau politică, culturală etc. Dar de ce și cum a fost posibil ca cerințele mediului să aibă șansa de „a fi ascultate”, inclusiv în direcția creării unui sistem de comunicare prin ceea ce am ajuns să numim semne lingvistice, era o chestiune deloc sau, în cel mai bun caz, neconvingător explicată pînă nu demult. Astfel încît, mai ales din partea specialiștilor aflați la capătul celălalt, proxim, al istoriei limbii, pare îndreptățită instalarea într-un soi de suficiență a neelucidatului și de acceptare a rezolvării celei mai simple a problemei: nedeschiderea ei.

Ideea s-a născut din constatarea faptului că în creierul uman regiunea sistemului oglindă, corespunzătoare zonei F5 din creierul macacilor, include așa-numita arie Broca, asociată tradițional cu vorbirea.

Se părea, așadar, că a stabili o legătură între (a) neuronii oglindă, (b) imitare (simplă $\rightarrow$ complexă) și (c) apariția/evoluția limbajului ar fi putut fi un demers deloc absurd. Și care ar fi explicat nu doar existența acestui tip de capacitate comunicațională între indivizi, ci chiar existența unui creier ale cărui mecanisme să poată determina existența limbajului-așa-numitul creier pregătitpentru limbaj (engl. a language-ready brain). Abordarea dă întîietate perspectivei neurolingvistice, care urmărește mecanismele cerebrale implicate în percepția și producerea limbajului (Arbib, 2012, p. 48). Conceptul de creier pregătit pentru limbaj (i.e. o abilitate înnăscută de a achiziţiona gramatica unei/unor limbi) nu trebuie confundat cu cel de gramatică universală care, în teoria—periculos (i.e. din punct de vedere științific) de teleologică—a lui

\footnotetext{
${ }^{2}$ E.g. „al schimbului de informații și al cooperării”, „al consolidării relațiilor sociale”, „al pedagogiei tehnologice”, „al negocierii”, „al necesității de a domina grupuri rivale”, „al manipulării sociale”, „al specificului nișei (politice) în care s-a dezvoltat omul”, „al narării evenimentelor reale și imaginare”, „al lămuririi propriilor idei”, „al capacităţii omului de a-şi reprezenta lumea”, „al limbajului - consecință a inteligenței”...

${ }^{3}$ În fapt, rivalitatea este gratuită: în cele mai multe dintre aceste teorii, mobilul apariției limbajului este în esență unul singur și ține de răspunsul indivizilor la presiunea și solicitările mediului în care trăiesc; „cooperarea” (pentru obținerea hranei sau pentru respingerea unei forțe agresoare), „negocierea”, „socializarea” etc. sînt manifestări în chipuri diferite ale aceluiași fenomen.
} 
Chomsky $(1965,1980)$, reprezintă o structură computațională universală care funcționează ca gramaticăarhetip, fixată în genomul uman (așadar, o proprietate biologică, un dat genetic) ce se poate specializa astfel încît să devină/să producă gramaticile individuale ale limbilor ${ }^{4}$.

IPOTEZA. Ipoteza sistemului oglindă reprezintă acum, în esență, elaborarea de două decenii a ideii că mecanismele lingvistice au apărut și s-au dezvoltat peste sistemul neuronilor oglindă implicat în apucare, grefîndu-se pe acesta, profitînd de abilitățile sale și ,învățînd” de la el. Promotorii acesteia au găsit demonstrabilă ideea că sistemul neuronal care face posibilă suprapunerea dintre observare și execuție „provides a necessary bridge from 'doing' to 'communicating', as the link between actor and observer becomes a link between the sender and the receiver of each message” [ rom.: „oferă conexiunea necesară între 'a face' și 'a comunica', în măsura în care legătura dintre actor și observator devine legătura dintre emițătorul și receptorul fiecărui mesaj] (Rizzolatti \& Arbib, 1998, p. 188). Descoperirile la care au dus cercetările ulterioare au fost sintetizate într-o lucrare a specialistului în științe biologice și computaţionale, matematică și psihologie Michael A. Arbib (2012) .

Cartea dezvoltă trei ipoteze cruciale (p. 160-162), condiționate reciproc: 1. nu există o gramatică universală înnăscută; 2. starea propice limbii (engl. language-readiness) este multimodală—a evoluat ca sistem multimodal manual/facial/vocal, în trepte: a) la bază, protosemnul (protolimbaj gestual, cu un repertoriu deschis de semne); b) apoi, protovorbirea (protolimbaj vocalizat), care a pus la dispoziție „masa neurală critică” grație căreia c) limbajul s-a dezvoltat din protolimbaj, ca rezultat al inovațiilor culturale; 3 . mecanismele cerebrale care susțin limbajul au evoluat deasupra unui mecanism primitiv pre-hominid fără legătură, iniţial, cu comunicarea; acesta, i.e. sistemul oglindă responsabil de apucare, a oferit fundamentul evolutiv pentru paritatea lingvistică - proprietatea ce face ca o emisie simbolică (un cuvînt sau un enunţ, bunăoară) să aibă același înțeles pentru receptor, ca și pentru emițător.

Rezolvarea. Arbib (2012) sugerează existența mai multor etape cruciale în procesul care a dus la apariția limbajului articulat—din care se oprește asupra a șase, distribuite pe parcursul a trei ere:

\section{„Pre-Hominid}

1. A mirror system for grasping: matching action observation and execution for grasping. Shared with common ancestor of human and monkey

2. A simple imitation system for grasping. Shared with common ancestor of human and great apes

\section{Hominid Evolution}

3. A complex imitation system: complex imitation combines the ability to recognize another's performance as a set of familiar movements with the ability to use this recognition to repeat

\footnotetext{
${ }^{4}$ Deși teoria a fost gîndită pentru limba engleză!

Pentru o scurtă și eficientă trecere în revistă a argumentelor pentru care conceptul de gramatică universală propus de Chomsky (și preluat în diferite forme de adepți mai mult sau mai puțin carismatici) nu este plauzibil, v. Christiansen \& Chater (2008 - și comentariile ulterioare a diverși cercetători, cu răspunsul autorilor la acestea). Rămîn solide intervențiile relativ timpurii ale lui Tomasello (1995; v. și Tomasello et al., 1993) contra gramaticii generative și a nativismului lingvistic afirmate de Chomsky, și a instinctului lingvistic susținut de Steven Pinker-acesta din urmă meritînd a fi luat în considerare în vederea criticii numai în măsura în care se identifică cu teoria gramaticii universale; altminteri, judecînd după valoarea denotativă a numelui său, ipoteza instinctului lingvistic este a priori nulă, deoarece contravine simplei definiții operaționale a instinctului: „a behavioral competency, or set of behavioral competencies, that: (a) is relatively stereotyped in its behavioral expression, and (b) would appear in ontogeny even if an individual were raised in isolation from its species-typical set of experiences" (Tomasello, 1995, p. 132-133).

${ }^{5}$ Cartea poate fi înscrisă în categoria celor de popularizare a unei cunoașteri dobîndite prin (re)interpretarea datelor revelate de studii de maximă și îngustă specialitate, solicitînd însă ceva mai mult decît rudimentare noțiuni de biologie, evoluționism, etologie, paleontologie umană, neurologie, arheologie preistorică, primatologie comparată ș.a. și, totodată, disponibilitatea de a renunța la unghiuri tradiționale și, poate de aceea, comode de scrutare a realității, ce ne fac să reiterăm la nesfîrșit, ca pe descoperiri mereu surprinzătoare, ceea ce este, de fapt, evident pentru toată lumea.
} 
the performance, and (more generally) to recognize that another's performance combines actions that can be imitated at least crudely by variants of actions already in the repertoire, with increasing practice yielding increasing skills

4. Protosign: a manual-based communication system, breaking through the fixed repertoire of primate vocalizations to yield an open repertoire

5. Protospeech and multimodal protolanguage: this rests on the "invasion" of the vocal apparatus by collaterals from communication system based on F5/Broca's area

\section{Cultural Evolution in Homo Sapiens}

6. Language: the transition from action-object frames to verb-argument structures which express them; syntax and a compositional semantics: Co-evolution of cognitive \& linguistic complexity"

[rom.: „Pre-Hominid

1. Un sistem oglindă pentru apucare: corespondența dintre observarea acțiunii de a apuca și executarea ei. Aceeași și la strămoşul comun al omului și al maimuței

2. Un sistem simplu de imitare pentru apucat. Același și la strămoşul comun al omului și al maimuțelor antropoide

\section{Evoluţia Hominidă}

3. Un sistem complex de imitare: imitarea complexă combină abilitatea de a identifica o activitate oarecare a cuiva ca set de gesturi familiare, cu abilitatea de a profita de această identificare în vederea repetării activității respective și cu abilitatea de a înțelege că în activitatea respectivă sînt combinate acțiuni ce pot fi imitate, fie și grosolan, prin apelul la variante ale acțiunilor deja existente în repertoriul observatorului; exercițiul repetat ducînd la îmbunătățirea performanței

4. Protosemn: un sistem de comunicare bazat pe gestul manual, care depășește repertoriul fix de vocalizări al primatelor, instituind un repertoriu deschis

5. Protovorbire și protolimbaj multimodal: se sprijină pe 'invadarea' aparatului vocal de către elemente colaterale din sistemul de comunicare din aria F5/Broca

\section{Evoluţie Culturală la Homo Sapiens}

6. Limbă: trecerea de la tipurile acțiune-obiect la structuri verb-elemente dependente care le exprimă; sintaxă și semantică compozițională; Co-evoluția complexității cognitive și lingvistice"] ${ }^{a}$

(Arbib, 2012, p. 174)

Ceea ce propune Arbib, oarecum contraintuitiv, nu este însă o înşiruire liniară de evenimente și etape ce culminează cu apariția limbii, în sensul unei transformări graduale a unui sistem într-un altul. Etapele (engl. stages) postulate de și în ipoteza sistemului oglindă sînt dezvoltări în rețea multidimensională ale unor mecanisme care, în vreme ce se rafinează și se îndepărtează de trunchiul/urile care le-a/au generat, lasă originarul suport să evolueze (performîndu-și funcțiile și răspunzînd unor nevoi și presiuni specifice din partea mediului), contribuie într-o oarecare măsură la întărirea acestuia și beneficiază „de la distanță” de optimizările cîștigate de acesta pe parcurs. Astfel, odată dobîndit sistemul complex de imitare-i.e. a) abilitatea de a analiza și de a recunoaște în comportamentul cuiva un set de gesturi familiare executate în vederea atingerii anumitor scopuri intermediare, b) abilitatea de a imita, cu o oarecare plasticitate, comportamentul observat, și c) abilitatea de a recunoaște că cineva introduce în comportamentul său gesturi noi, ce pot fi imitate mai mult sau mai puțin acurat prin apelul la variante ale acțiunilor deja existente în

aTraducerea fragmentelor excerptate ne aparține și face parte dintr-un demers ce vizează publicarea în limba română a cărții, întreprins împreună cu Pál Enikö. 
repertoriul observatorului (v. supra; și, de asemenea, p. 188, 214, 263) ${ }^{6}$-, răspunsul evolutiv a luat forma emergenței capacităţii de (panto)mimare (engl. pantomime), a cărei esență constă în intenția de a trezi în mintea observatorului gîndul la un anumit lucru sau eveniment. Față de simpla imitare, în care fluxul informației este unidirecțional, oprindu-se la imitatorul care doar observă și reproduce-am putea spune, pentru sine-, mimarea este de natură comunicativă, cel care mimează preluînd informația de undeva și executînd gesturile ce fac aluzie la ea cu intenția de a fi observat și de a obține o reacție de la celălalt. Se poate vorbi în acest moment de un protolimbaj a cărui materie o constituie gesturile manuale (i.e. protosemnul) - structură pe care se așază și se dezvoltă un protolimbaj a cărui materie o constituie gesturile vocale (i.e. protovorbirea). Primul Homo sapiens ajunge deci la stadiul de a poseda două modalități de comunicare nu prin descoperirea în sine, prin învățare, a unei capacități ascunse/latente a creierului său; ci prin faptul că creierul său își creează, fizic (i.e. evoluție biologicăă, care include și crearea unei baze genetice favorabile limbajului), această capacitate:

"the evolution of a system for voluntary control of intended gestural communication based in part on F5/Broca's area provided the basis for the evolution of creatures with more and more prominent connections from F5/Broca's area to the vocal apparatus. This in turn could provide conditions that led to a period of coevolution of the vocal apparatus and its integration with the neural circuitry for control of gesture and protosign."

[rom: „evoluţia unui sistem pentru controlul voluntar al comunicării gestuale intenționate bazat în parte pe aria F5/Broca a oferit fundamentul pentru evoluția unor indivizi cu din ce în ce mai robuste conexiuni între aria F5/Broca și aparatul vocal. La rîndul lui, acest fapt a oferit premisele unei perioade de coevoluție a aparatului vocal și ale integrării sale cu circuitul neural pentru controlul gestului și protosemnului.”]

(Arbib, 2012, p. 231)

Arbib introduce în chestiunea apariției limbajului un concept care nu este nou în teoriile evoluției ${ }^{7}$, cel al spiralei în progresie continuă (engl. expanding spiral); ipoteza aceasta presupune că cele două modalități primitive de comunicare nu cunosc o consecutivitate pură: se stimulează şi se modelează reciproc, ambele constituind un avantaj în selecția naturală, astfel încît protosemnul ajunge la statutul unui limbaj abia odată cu apariția primelor forme de protovorbire (p. 178, 261). În lumina a ceea ce avea să se întîmple ulterior în filogeneză, creierul ce posedă capacitatea de a genera și coordona gesturi manuale, faciale și vocale convenționale în vederea comunicării-într-un repertoriu deschis, ce depășește datul genetic (cu "gesturi” instinctuale distribuite la „situaţii” specifice)—este un creier pregătit pentru vorbirea propriuzisă, cu toate că îi lipsesc, deocamdată, pentru încă cîteva zeci de mii de ani, sintaxa, semantica și expresivitatea complexe și structurile conceptuale ce stau la baza limbii unui Homo sapiens modern.

Acestei viziuni asupra evoluţiei limbajului uman, expuse mai întîi în Arbib (2005; cf. Wray, 1998, 2002), i s-au adus critici (e.g. Tallerman, 2007) ce fac aluzie la insuficiența-în termenii supraviețuirii speciei și ai avantajului asupra altora, concurente-punerii în acțiune a unei atare „gramatici parțiale” și, în consecință, la inconsistența teoriei. Oricît de argumentate în plan analitic-sincronic (i.e. modern), asemenea obiecții au în structura lor un punct șubred, ce constă în evaluarea inexactă a circumstanțelor comunicării, în sens larg (puterea cognitivă a speciei, interesele ei, proeminența pentru indivizii speciei a unor elemente din cîmpul situațional și nu a altora etc.). Anacronismul teoretic este sancționabil:

„One must not think of protohumans as having modern thoughts and just lacking the ability to express them. Protohumans would not have the idea of trying to pantomime the equivalent of arbitrary complex sentences. Rather, they would have had a small stock of protowords that

\footnotetext{
${ }^{6}$ Toate acestea implicînd faptul că „mirror neurons are not restricted to recognition of an innate set of actions but can be recruited to recognize and encode an expanding repertoire of novel actions" (Arbib, 2012, p. 131).

${ }^{7}$ Și în știință, în general (v. Gafton \& Gafton, 2017), unde se preferă însă 'coevoluție' (v. și fragmentul citat mai sus).
} 
would increase over the generations as pantomimes and vocal performances became conventionalized for situations of sufficient importance or frequency."

[rom.: „Nu trebuie să ne gîndim la proto-oameni ca la niște ființe capabile de gînduri moderne dar incapabile de a și le exprima. Proto-oamenii nu erau chinuiți de ideea de a încerca să mimeze echivalentul unor arbitrare enunțuri complexe. În schimb, aveau la îndemînă o mică rezervă de protocuvinte, în creștere de la o generație la alta, pe măsură ce gesturile manuale și execuțiile vocale deveneau convenționale pentru diverse situații suficient de importante și de frecvente.”]

(Arbib, 2012, p. 259)

Trecerea de la o paradigmă a comunicării bazată pe gest și numire rudimentară (starea alingvistică, p. 268) la una bazată pe structuri mai mult sau mai puțin complexe, cu centru verbal și elemente sintactice dependente de acesta (starea lingvistică) reprezintă produsul evoluției culturale (în esență, epigenetică ${ }^{8}$ ) — posibilă datorită evoluției biologice a speciei, la nivelul creierului și al corpului-, înțeleasă ca serie de procese ce modelează miriade de fațete ale umanității în modalități care sînt relativ independente de biologia umană (p. viii). Din nou, procesul poate fi reprezentat mai acurat ca spirală evolutivă, în care lexiconul și sintaxa limbii (de fapt, ale limbilor diferitelor grupuri de Homo sapiens existente deja ${ }^{9}$ ) nu reprezintă etape separate, ci se înfiripă și se dezvoltă concomitent.

Demonstrarea plauzibilității ipotezei sistemului oglindă ca bază primară a modelării unui creier apt (pregătit) pentru limbaj, prin imitarea complexă (mecanism analitic, multimodal și cumulativ; v. supra), se sprijină, în sfîrșit, pe ceea ce se poate observa în legătură cu emergența și evoluția unor „limbi gestuale”sisteme de comunicare gestuală proprii comunităților ai căror indivizi sînt lipsiți de capacitatea de a vorbi și auzi ${ }^{10}$. Deși asemenea limbi au o geneză și o evoluție specifice, diversele etape ale istoriei lor pot fi interpretate ca puneri în act ale proceselor de observare și analiză a gesturilor cu potenţial comunicativ și de construcție a unora noi (impuse de situația de comunicare), cu elemente „recuperate” în urma deconstrucției celor originare și „redistribuite”. Mai mult, sintaxa lor nu imită sintaxa variantei vorbite a limbilor respective, ci reprezintă mai degrabă o oglindă a structurii și a circumstanței acțiunii comunicate sau ale obiectului comunicat.

Deși în cazul limbii ontogeneza nu recapitulează filogeneza, achiziția limbii de către un copil sau emergența uneia noi, astăzi, se produce grație acelorași mecanisme cerebrale, modelate biologic, care au făcut posibile apariția limbajului și modelarea lui culturală. Or,

„[i]f a child sees a complicated sign, he or she will successfully mimic one or two features at first. I would thus suggest that what might look like breaking complex verb expressions down into sequential morphemes may be a matter of motor simplification rather than a linguistic reanalysis. Breaking complex skills into pieces and then learning how to gracefully reconstitute them is a general property of motor learning, and it should not be counted as a design feature specific to language"

\footnotetext{
${ }^{8}$ În cadrul teoriilor evoluţioniste, cei care se întorc înspre darwinism prin respingerea soluției reducționiste a neodarwiniștilor, reincluzînd în ecuație poziția lamarckistă, dezvoltă în ultima vreme o viziune pluridimensională a evoluției (v. Jablonka \& Lamb, 2019). Deși identitatea dintre evoluția epigenetică și cea culturală (segmentată în simbolică și, în parte, comportamentală) nu este asumată explicit, acumularea observațiilor de natură empirică asupra tuturor speciilor, cu diferențele de rigoare, ar impune-o.

V., pentru chestiunea factorului cultural în evoluția limbii, Dediu et al. (2013).

9 "It may never be possible to decide on linguistic grounds whether language developed just once (monogenesis) or separately in two or more places (polygenesis). And it will certainly never be possible for linguists to recover the structure of 'protoworld' if indeed monogenesis holds. Nonetheless, it seems more likely that multiple protolanguages developed well before there were languages with anything like the richness of modern human languages” (Arbib, 2012, p. 332).

${ }^{10}$ Este vorba, în mod concret, de Limba prin Semne Nicaraguană, și de Limba prin Semne a Beduinilor Al-Sayyd din Negev, Israel, care au apărut și s-au dezvoltat spontan, în comunităţi relativ închise, independent de alte sisteme similare, dar care posedau o „gramatică” și un „lexicon” standardizate.
} 
[rom.: „dacă un copil percepe un semn complicat, va începe prin a mima unul sau două aspecte legate de acesta. Înclin să cred că ceea ce ar putea părea o deconstrucție a unor expresii verbale complexe în morfeme secvențiale este mai degrabă o chestiune de simplificare motoare decît una de reanaliză lingvistică. A desface abilități complexe în bucăți și apoi a învăța cum să le refaci elegant reprezintă o proprietate generală a învăţării motoare, și nu ar trebui interpretată ca o caracteristică de plan specifică limbii”]

(Arbib, 2012, p. 319)

EpILOG. Ca în cazul oricărui adevăr ce nu poate fi probat prin observare la fața locului (sau a... timpului, în cazul de față), urmărirea chestiunii apariției limbajului articulat și, eventual, mai înainte de aceasta, a formării mecanismului cerebral care l-a făcut posibil expune cercetătorul la riscul de a părea că nu izbutește altceva decît o teorie speculativă. Elegantă (în termeni matematici ${ }^{11}$ ), mesmerizatoare poate, consistentă și coerentă în cadrul fixat de ea însăşi, dar vulnerabilă în faţa vreunei paradigme de gîndire care operează cu detalii precise din varii domenii, care trebuie să se armonizeze, care sînt relevante și i se aplică, de fapt, și care ar fi trebuit luate în considerare de la început. Ipoteza neuronilor oglindă a lui Michael A. Arbib este, încă, singura care se ține departe de acest risc prin faptul că se lasă orientată și modelată de o viguroasă interdisciplinaritate, care îşi cunoaște și îşi apără, pe domenii, certitudinile individuale.

În anii din urmă, cercetările desfășurate asupra acelorași probleme ${ }^{12}$ continuă să ofere dovezi analitice și empirice care fac din ipoteza lui Michael A. Arbib o teorie robustă-în sens sistemic.

\section{Bibliografie}

Arbib, M.A. (2005). From monkey-like action recognition to human language: An evolutionary framework for neurolinguistics, în „Behavioral and Brain Sciences”, 28 (2), p. 105-124, Crossref.

Arbib, M. A. (2012). How the Brain Got Language. The Mirror System Hypothesis, Oxford University Press, Crossref.

Arbib, M.A. (ed.) (2018). How the Brain Got Language. Towards a New Road Map, număr special al „Interaction Studies. Social Behaviour and Communication in Biological and Artificial Systems", 19 (1-2), Crossref.

Chomsky, N. (1965). Aspects of the theory of syntax, MIT Press, Crossref.

Chomsky, N. (1980). Rules and representations, Columbia University Press / Blackwell.

Chong, T.T., Cunnington, R., Williams, M.A., Kanwisher, N. \& Mattingley, J.B. (2008). fMRI adaptation reveals mirror neurons in human inferior parietal cortex, în „Current Biology”, 18 (20), p. 1576-1580, Crossref.

Christiansen, M.H. \& Chater, N. (2008). Language as Shaped by the Brain, în „Behavioral and Brain Sciences”, 31, p. 489-558, Crossref.

Corballis, M.C. (2015). What's left in language? Beyond the classical model, în „Annals of the New York Academy of Science”, 1359 (1), p. 1-16, Crossref.

Corballis, M.C. (2017). The evolution of lateralized brain circuits, în „Frontiers in Psychology”, 8, Crossref.

Corballis, M.C. (2019). Minimalism and Evolution, în „Frontiers in Communication”, 4, Crossref.

Dediu, D. et al. (2013). Cultural Evolution of Language, în Richerson, P.J. \& Christiansen, M.H. (eds), Cultural Evolution: Society, Technology, Language, and Religion, MIT Press, p. 303-332.

Di Pellegrino, G., Fadiga, L., Fogassi, L., Gallese, V. \& Rizzolatti, G. (1992). Understanding motor events: a neurophysiological study, în „Experimental Brain Research”, 91 (1), p. 176-180, Crossref.

Fogassi, L., Ferrari, P.F., Gesierich, B., Rozzi, S., Chersi, F. \& Rizzolatti, G. (2005). Parietal lobe: from action organization to intention understanding, în „Science”, 308, p. 662-667, Crossref.

Gafton, Al. \& Gafton, E. (2017). Realitate, stiință, metodă, în „The Proceedings of the International Conference «Globalization and intercultural dialogue: multidisciplinary perspectives»”, 4, Arhipelag XXI Press, Tîrgu Mureş, p. 9-24.

Gallese, V., Fadiga, L., Fogassi, L. \& Rizzolatti, G. (1996). Action recognition in the premotor cortex, în „Brain”, 119 (2), p. 593609, Crossref.

Heyes, C. (2010). Mesmerising mirror neurons, în „Neuroimage”, 51 (2), p. 789-791, Crossref.

Jablonka, E. \& Lamb, M.J. (2019). Patru dimensiuni ale evoluţiei. Variație genetică, epigenetică, simbolică și comportamentală, ediție îngrijită și traducere de Al. Gafton \& A. Chirilă, Casa Editorială „Demiurg”, Iași.

Kilner, J., Neal, A., Weiskopf, N., Friston, K.J. \& Frith, C. (2009). Evidence of mirror neurons in human inferior frontal gyrus, în „Journal of Neurosci., 29 (32), p. 10153-10159, Crossref.

\footnotetext{
${ }^{11}$ Chomskyanismului, de pildă, i s-a recunoscut această calitate (v. Tomasello, 1995, p. 136).

${ }^{12}$ V., e.g., articolele publicate în Arbib (2018); de asemenea, Corballis (2015, 2017, 2019).
} 
Kilner, J. M. \& Lemon, R.N. (2013). What We Know Currently about Mirror Neurons, în „Current Biology”, 23 (23), p. 10571062, Crossref.

Molenberghs, P., Cunnington, R. \& Mattingley, J. B. (2012). Brain regions with mirror properties: a meta-analysis of 125 human fMRI studies, în „Neuroscience \& Biobehavioral Reviews”, 36 (1), p. 341-349, Crossref.

Mukamel, R., Ekstrom, A.D., Kaplan, J., Iacoboni, M. \& Fried, I. (2010). Single-neuron responses in humans during execution and observation of actions, în „Current Biology”, 20 (8), p. 750-756, Crossref.

Press, C., Weiskopf, N. \& Kilner, J.M. (2012). Dissociable roles of human inferior frontal gyrus during action execution and observation, în „Neuroimage”, 60 (3), p. 1671-1677, Crossref.

Rizzolatti, G., Fadiga, L., Gallese, V., Fogassi, L. (1996). Premotor cortex and the recognition of motor actions, în „Cognitive Brain Research", 3 (2), p. 131-141, Crossref.

Rizzolatti, G. \& Arbib, M.A. (1998). Language within our grasp, în „Trends in Neuroscience”, 21 (5), p. 188-194, Crossref.

Rizzolatti, G. \& Fogassi, L. (2014). The mirror mechanism: recent findings and perspectives, în „Philosophical Transactions of the Royal Society B", 369 (1644), Crossref.

Tallerman, M. (2007). Did our ancestors speak a holistic protolanguage?, în „Lingua”, 117 (3), p. 579-604, Crossref.

Tomasello, M. (1995). Language Is Not an Instinct. Book review: S. Pinker, The Language Instinct: How the Mind Creates Language, New York, William Morrow, 1994, în „Cognitive Development”, 10 (1), p. 131-156, Crossref.

Tomasello, M., Kruger, A., \& Ratner, H. (1993). Cultural Learning, în „Behavioral and Brain Sciences”, 16 (3), p. 495-552, Crossref.

Wray, A. (1998). Protolanguage as a holistic system for social interaction, în „Language and Communication”, 18 (1), p. 47-67, Crossref.

Wray, A. (2002). The Transition to Language, Oxford University Press. 